COX-2 Inhibitory Activity of Homoisoflavanones and Xanthones from the Bulbs of the Southern African Ledebouria socialis and Ledebouria ovatifolia

\title{
(Hyacinthaceae: Hyacinthoideae)
}

Catherine P. Waller, ${ }^{\mathrm{a}}$ Alfred E. Thumser, ${ }^{\mathrm{d}}$ Moses K. Langat, ${ }^{\mathrm{a} b}$ Neil R. Crouch,, Dulcie A. Mulholland ${ }^{\mathrm{a}, \mathrm{b}, *}$

${ }^{a}$ Natural Products Research Group, Department of Chemistry, University of Surrey, Guildford, GU2 7XH, Surrey, UK.

${ }^{\mathrm{b}}$ School of Chemistry and Physics, University of KwaZulu-Natal, Durban, 4041, South Africa.

${ }^{\mathrm{c}}$ Ethnobotany Unit, South African National Biodiversity Institute, PO Box 52099, Berea Road 4007, Durban, South Africa.

${ }^{\mathrm{d}}$ Division of Biochemical Sciences, Faculty of Health and Medical Sciences, University of Surrey, Guildford, GU2 7XH, Surrey, UK.

Abstract: The bulbs of Ledebouria socialis (Hyacinthaceae) yielded the novel benzocyclobutene homoisoflavonoid, $\quad(R)$-2', 5-dihydroxy-3', 4', 7trimethoxyspiro $\{2 H$-1-benzopyran-3-(4H)-9-bicyclo[4.2.0] octa[1,3,5]triene $\}$-4-one, socialinone (1). Ledebouria ovatifolia yielded (2ع,3R)-2,5-dihydroxy-7methoxyspiro[2H-1-benzopyran-3(4H), $5^{\prime}\left(6^{\prime} \mathrm{H}\right)$-cyclobuta[f][1,3]benzodioxol]-4-one (2) and the novel homoisoflavanone, (E)-3-(3',4'-dihydroxybenzylidene)-5,7dihydroxychroman-4-one, ovatifolionone (5), the novel dihydrochalcone, 4,4'dihydroxy-2',6'-dimethoxydihydrochalcone (3), and xanthone, 1,6-dihydroxy-2,3,5trimethoxy-8-methyl-9H-xanthen-9-one (4) along with twenty-one known compounds. Structures were determined using spectroscopic techniques. The antiinflammatory activities of the homoisoflavonoids and xanthones isolated were evaluated against cyclooxygenase-1 and -2 isoenzymes. (R)-3-(3',4'Dihydroxybenzyl)-7-hydroxy-5-methoxychroman-4-one $\quad(7), \quad(E)-3-\left(3^{\prime}, 4^{\prime}-\right.$ dihydroxybenzylidene)-7-hydroxy-5-methoxychroman-4-one (10), 1,3,6-trihydroxy2-methoxy-8-methylxanthen-9-one (6) and ovatifolionone acetate (5Ac) exhibited significant activity against cyclooxygenase- 2 at $<10 \mu \mathrm{M}$.

\footnotetext{
* Corresponding author. Department of Chemistry, Faculty of Engineering and Physical Sciences, University of Surrey, Guildford, GU2 7XH, Surrey, UK. Tel,: +44 1483686751.

E-mail address: d.mulholland@surrey.ac.uk (Mulholland, D.A.)
} 
Keywords: Hyacinthaceae, Ledebouria ovatifolia, Ledebouria socialis, homoisoflavanone, xanthone, socialinone, ovatifolionone, anti-inflammatory, cyclooxygenase activity.

\section{Introduction:}

Ledebouria Roth of the Hyacinthaceae is a genus consisting of approx. 60 species, mostly sub-Saharan, with one or two species each in Madagascar and India, and with its centre of diversity in northeastern South Africa (Venter, 2008). Ledebouria was previously considered congeneric with a broadly conceived Scilla L. but subsequently reinstated by Jessop (1970). In previous pharmacological investigations, homoisoflavanones, commonly occurring constituents in the Hyacinthoideae (Speta 1998; Pohl et al., 2000), have been found to have anti-inflammatory activity (Della Loggia et al., 1989; Abegaz et al., 2007).

The phytochemistry of several members of Ledebouria have been investigated previously (Pohl et al., 2000, 2001; Mutanyatta et al., 2003), including both species reported in the current account. The widespread Ledebouria ovatifolia (Bak.) Jessop exhibits high polymorphism, with several entities currently synonymised under this name. This prompted a re-investigation of this species. The bulbs of L. ovatifolia are used in African traditional medicine to treat backache, influenza and gastro-enteritis (Hutchings et al., 1996); it is further used as a soap and for ethnoveterinary purposes (Gerstner, 1938). Contrasting reports on the toxicity of this species to mammalian test subjects exist (Steyn, 1936; Van der Walt and Steyn, 1941). The second subject of this investigation, Ledebouria socialis (Bak.) Jessop is localised in the Eastern Cape Province of South Africa, and exists as both green and silver-leaved forms. From the ethyl acetate extract of Ledebouria socialis (as Scilla socialis Bak.), Kato et al., (2007) yielded eleven hyacinthacines, two pyrrolidines and three piperidines. The methanol extract of Ledebouria ovatifolia earlier yielded two compounds 4,4'dihydroxy-2',6'-dimethoxychalcone and 5,7-dihydroxy-3-(4'-hydroxybenzyl)-4chromanone (Pohl et al., 2001). 
Cyclooxygenase is responsible for the synthesis of prostaglandins in acute inflammatory conditions (O'Banion et al., 1992). Non-selective inhibitors of cyclooxygenase decrease the inflammatory response but have also been linked to gastro-intestinal tract bleeding at high doses (Smith et al., 2000). Selective COX-2 inhibitors decreased this effect but were found to have cardiac implications (Cipollone et al., 2008). It has also been demonstrated in several studies that cyclooxygenase inhibitors can have cancer preventative effects (Giardiello et al., 1995; Levy, 1997) especially when specific against cyclooxygenase- 2 .

As the Hyacinthoideae has been shown to contain anti-inflammatory homoisoflavanones using the mouse oedema test (Della Loggia et al., 1989), the homoisoflavanones and xanthones isolated from the two plants were screened for cyclooxygenase activity. Reported herein is the isolation of five novel compounds along with twenty-five known compounds from the bulbs of both $L$. socialis and $L$. ovatifolia. The anti-inflammatory activities of selected isolates were evaluated.

\section{Results and discussion:}

The dichloromethane extract of the bulbs of L. socialis was separated by normal phase column chromatography over silica gel to afford one novel homoisoflavanone, socialinone (1) as well as (R)-5-hydroxy-7,2',3',4'-tetramethoxyspiro\{2H-1benzopyran-3-(4H)-9-bicyclo[4.2.0]octa[1,3,5]-triene\}-4-one, isolated previously from Drimiopsis barteri (Ngamga et al., 2008), and phytol and stigmasterol. The methanol extract was separated using normal phase column chromatography and yielded the known compound polybotrin (Zou et al., 2007), which has not been reported previously from the Hyacinthaceae. The dichloromethane, ethyl acetate and methanol extracts of bulbs of L. ovatifolia were separated by normal phase column chromatography over silica gel to afford twenty-five compounds. The dichloromethane extract yielded compound 2, reported previously (Kawasaki et al., 1973) as a mixture of diastereomers, which we separated after acetylation and were able to assign the respective absolute configurations using 2D NMR and CD spectroscopy, a novel dihydro-chalcone (3), and a novel xanthone (4). Also isolated from this extract were the known compounds (R)-5,7-dihydroxy-3-(4'hydroxybenzyl)chroman-4-one (Adinolfi et al., 1987) and (E)-4,4'-dihydroxy-2',6'- 
dimethoxychalcone (Sun et al., 1989) which had both been isolated previously from Ledebouria ovatifolia (Pohl et al., 2001), scillascillin (Kawasaki et al., 1973), 1,6dihydroxy-3-methoxy-8-methyl-9H-xanthen-9-one (McMaster et al., 1960; Mutanyatta et al., 2003), (R)-4',5,7-trihydroxy-3'-methoxyspiro\{2H-1-benzopyran3(4H)-9-bicyclo[4.2.0]octa[1,3,5]triene\}-4-one (Adinolfi et al., 1985), (R)-3',5,7trihydroxy-4'-methoxyspiro\{2H-1-benzopyran-3(4H)-9-

bicyclo[4.2.0]octa[1,3,5]triene \}-4-one (Adinolfi et al., 1987), (R)-5,7-dihydroxy-3(4'-methoxybenzyl)chroman-4-one (Heller et al., 1976), eucomol (Bohler and Tamm, 1967), and (R)-7-hydroxy-3-(4'-hydroxybenzyl)-5-methoxychroman-4-one (Finckh and Tamm, 1970) which had been isolated previously from the Hyacinthaceae, and coniferaldehyde (Seikel et al., 1971) and chondrillasterol (Bergmann and Feeney, 1948) which had not been isolated previously from this family. The ethyl acetate extract yielded one novel homoisoflavanone, ovatifolionone (5), and the known compounds, drimiopsin C (Mulholland et al., 2004), norlichexanthone (Aghoramurthy and Seshadri, 1953; Mutanyatta et al., 2003), 22-acetoxy-15deoxoeucosterol (Amschler et al., 1997; Pohl et al., 2001), (R)-(3-(3',4'dihydroxybenzyl)-5,7-dihydroxychroman-4-one (Adinolfi et al., 1987, 4'-demethyl-5$O$-methyl-dihydroeucomin (Finckh and Tamm, 1970), (R)-3-(3',4'-dihydroxybenzyl)7-hydroxy-5-methoxychroman-4-one (Adinolfi et al., 1987), and (E)-3-(3',4'dihydroxybenzylidene)-7-hydroxy-5-methoxychroman-4-one (Masterova et al., 1991) which have all been isolated from the Hyacinthaceae previously and $p$-anisic aldehyde (Gottlieb et al., 1970) and 4-hydroxyphenylethanol (Gharbo et al., 1970) which have not been reported from this family. The methanol extract also yielded polybotrin (Zou et al., 2007). Interestingly, this compound was isolated from both species in this study. The known compounds were identified by analysis of their spectroscopic and spectrometric data and comparison with literature data.

Compound 1, (R)-2',5-dihydroxy-3',4',7-trimethoxyspiro\{2H-1-benzopyran-3-(4H)9-bicyclo[4.2.0]octa[1,3,5]triene\}-4-one, was obtained as a yellow oil. The IR absorption bands at 3455 and $1737 \mathrm{~cm}^{-1}$ indicated the presence of hydroxyl and carbonyl functional groups, respectively. This compound was identified as the 2'hydroxylated derivative of the known 5-hydroxy-7,2',3',4'-tetramethoxyspiro $\{2 \mathrm{H}-1$ benzopyran-3-(4H)-9--bicyclo[4.2.0]octa[1,3,5]-triene\}-4-one (Ngamga et al., 2008), also isolated in this work. The ${ }^{1} \mathrm{H}$ NMR spectrum showed a sharp resonance at $\delta$ 
12.05 ascribable to the hydrogen bonded hydroxyl group proton at C-5, two metacoupled proton resonances $(\delta 6.09, \mathrm{~d}, J=2.3 \mathrm{~Hz}, \delta 6.05, \mathrm{~d}, J=2.3 \mathrm{~Hz})$ ascribable to H-6 and H-8, resonances ascribed to the two H-2 $(2 \mathrm{H}, \delta 4.55)$ and two $\mathrm{H}-9(\delta 3.62, \mathrm{~d}$, $J=13.1 \mathrm{~Hz}, \delta 3.02, \mathrm{~d}, J=13.1 \mathrm{~Hz}$ ) resonances of a scillascillin-type of homoisoflavonoid. The H-5' resonance $(\delta 6.29$, s) showed correlations in the HMBC spectrum with C-3, C-3' and C-1' resonances. A hydroxyl group was placed at C-2' due to correlations between the hydroxyl group proton resonance $(\delta 5.84, \mathrm{~s})$ and the C-1'and C-3' resonances in the HMBC spectrum. Methoxy groups $(\delta 3.84, \delta 3.80, \delta$ 3.86) were placed, in agreement with the NOESY spectrum, at the remaining C-7, C4' and C-3' positions. The ECD spectrum of Compound 1 showed a positive Cotton effect at $297 \mathrm{~nm}$ and a negative Cotton effect at $340 \mathrm{~nm}$ confirming the $(R)$ configuration at C-3 (Adinolfi et al., 1990).

Compound 2 is the C-2 hydroxylated, C-3'/C-4'-methylenedioxy derivative of Compound 1. The hemiacetal ring $\mathrm{C}$ opens and closes in solution, making it impossible to obtain a pure compound. Acetylation yielded compounds $\mathbf{2}(\boldsymbol{R})$ and $\mathbf{2}(S)$ which could be separated, and the absolute configuration at C-2 of the diastereomers was confirmed using NMR and CD experiments. Compound $\mathbf{2}$ has previously been reported from Barnardia japonica (as Scilla scilloides) (Kawasaki et al., 1973).

Compound 2(R), the 2,5-diacetoxy derivative of $\mathbf{2}$, was isolated as a clear oil. The ${ }^{1} \mathrm{H}$ NMR spectrum showed the H-2 resonance $(\delta 6.48, \mathrm{~s})$ and the typical H-9 proton resonances $(\delta 3.33, \mathrm{~d}, J=13.5 \mathrm{~Hz}, \delta 3.20, \mathrm{~d}, J=13.5 \mathrm{~Hz})$. Resonances at $\delta 6.67$ and $\delta$ 6.61 appeared as singlets indicating their para-relationship and were assigned as H-2' and $\mathrm{H}-5$ ' respectively. Resonances due to protons of a C-3'/C-4' methylenedioxy group were seen at $\delta 5.91$ and $\delta 5.89$ (both $\mathrm{d}, J=1.3 \mathrm{~Hz}$ ). The NMR spectra of compound 2(S), differed slightly in the chemical shifts for H-2, 2H-9, H-2' and H-5' as shown in Table 1. The absolute configuration at C-2 of $\mathbf{2}(\boldsymbol{R})$ and $\mathbf{2}(\boldsymbol{S})$ was established using ECD experiments. Compound $\mathbf{2}(\boldsymbol{R})$ showed a negative Cotton effect at $300 \mathrm{~nm}$ and Compound $\mathbf{2}(\boldsymbol{S})$ a positive Cotton effect at $307 \mathrm{~nm}$. The experimental ECD spectra of the two compounds were compared to their calculated spectra. Conformational analysis of compounds $2(\boldsymbol{R})$ and $2(S)$ were performed on Spartan08 using MMFF (Devlin et al., 2009) and the global minimum conformers subjected to TDDFT calculations employing the functional B3LYP and a basis set of 
6-31G (d, f), built into Gaussian09 software (Burgueno-Tapia et al., 2006; Felippe et al., 2012). The calculated ECD spectra of the global minimum conformers were compared to the experimental spectra [Figure 2]. The TDDFT simulated and experimental ECD spectra of compound $\mathbf{2}(\boldsymbol{R})$ were compared and both showed negative Cotton effects at $230-400 \mathrm{~nm}$ confirming that compound $2(\boldsymbol{R})$ had the $2 R, 3 R$ configuration. The TDDFT simulated ECD spectrum obtained for Compound $2(S)$ was UV corrected and compared to the experimental ECD spectrum supporting a $(2 S$, $3 R)$ configuration for Compound 2(S) [Figure 2].

Compound 3, 4,4'-dihydroxy-2',6'-dimethoxydihydrochalcone, was isolated as a white powder from the dichloromethane extract of L. ovatifolia. HRESIMS indicated a molecular formula of $\mathrm{C}_{17} \mathrm{H}_{18} \mathrm{O}_{5}$ and IR absorption bands at 3377 and $1736 \mathrm{~cm}^{-1}$ indicated hydroxyl and carbonyl groups. Two coupled methylene proton resonances $(2 \mathrm{H}, \delta 2.92, \mathrm{t}, J=7.7 \mathrm{~Hz} ; 2 \mathrm{H}, \delta 3.01, \mathrm{t}, J=7.7 \mathrm{~Hz})$ indicated a dihydrochalcone structure. Para-substitution on ring C was confirmed by the presence of a pair of doublets, each integrating to $2 \mathrm{H}(\delta 7.07, \mathrm{~d}, J=8.5 \mathrm{~Hz} ; \delta 6.73, \mathrm{~d}, J=8.5 \mathrm{~Hz})$. Two equivalent methoxy groups $(6 \mathrm{H}, \delta 3.71, \mathrm{~s})$ were placed at $\mathrm{C}-2$ ' ' and $\mathrm{C}-6$ ' in agreement with correlations seen in the NOESY spectrum with the $\mathrm{H}-3^{\prime} / 5^{\prime}$, resonance $(2 \mathrm{H}, \delta$ $6.02, s)$, and $2 \mathrm{H}_{\alpha}$. The remaining two hydroxyl groups were placed at C-4 and C-4'.

Compound 4, 1,6-dihydroxy-2,3,5-trimethoxy-8-methyl-9H-xanthen-9-one, was isolated as a yellow powder from the $\mathrm{CH}_{2} \mathrm{Cl}_{2}$ extract of L. ovatifolia. HRESIMS indicated a molecular formula of $\mathrm{C}_{17} \mathrm{H}_{16} \mathrm{O}_{7}$ and IR absorption bands 3417 and 1643 $\mathrm{cm}^{-1}$ indicated the presence of hydroxyl and carbonyl groups. The ${ }^{1} \mathrm{H}$ NMR spectrum showed hydrogen bonding between the C-9 carbonyl group and a C-1 hydroxyl group proton $(\delta$ 13.26, s, H-1-OH). The C-8 methyl group proton resonance $(\delta 2.80$, s)(Mulholland et al., 2004), showed correlations in the COSY and NOESY spectra with the H-7 resonance $(\delta 6.75$, s). The NOESY spectrum showed correlations between the H-7/C-6-OH $(\delta 6.24, \mathrm{~s}), \mathrm{H}-6-\mathrm{OH} / \mathrm{C}-5-\mathrm{OMe}(\delta$ 4.05, s), C-5-OMe/H-4 $(\delta$ 6.46 , s)and $\mathrm{H}-4 / \mathrm{C}-3-\mathrm{OMe}(\delta 3.97$, s) proton resonances. The remaining methoxy group $(\delta 3.91, \mathrm{~s})$ was placed at C-2. This was confirmed by an HMBC correlation between the $\mathrm{C}-2(\delta$ 132.2) and the $\mathrm{H}-4$ resonances.

Compound 5, ovatifolionone, a 3-benzylidene-4-chromanone homoisoflavanone, was isolated as a yellow powder from the EtOAc extract of L. ovatifolia. Compound 5 
was acetylated to aid purification and formed a mono-acetate (5Ac). The molecular ion was not observed in the HRESIMS, but a peak at 299.0553, corresponding to a $[\mathrm{M}-\mathrm{OAc}]^{+}$ion was observed. The IR absorption bands at 3415, 1745 and $1638 \mathrm{~cm}^{-1}$ indicated hydroxyl, and acetate and ketone carbonyl stretches respectively. ${ }^{1} \mathrm{H}$ NMR and ${ }^{13} \mathrm{C}$ NMR spectra indicated a C-3(9)-double bond, with the $\mathrm{H}-9$ resonance occurring as a singlet at $\delta 7.58$. The $\mathrm{H}-2$ resonance $(2 \mathrm{H}, \delta 5.30, \mathrm{~d}, J=1.4 \mathrm{~Hz})$ showed a correlation in the COSY spectrum with the H-9 resonance and the C-3 resonance was observed as a quaternary carbon at $\delta$ 128.9. As no hydrogen-bonded 5-OH proton resonance was present, the acetate group was placed at C-5. This placement was confirmed by the chemical shift of the C-4 carbonyl carbon resonance which occurred at $\delta 180.4$ compared to the usual value of $\delta 186$ for $5-\mathrm{OH}$ benzylidene homoisoflavanones (Bangani et al., 1999). Resonances due to the meta-coupled H-6 and $\mathrm{H}-8$ protons occurred at $\delta 6.19$ and $\delta 6.26$ respectively (both $\mathrm{d}, J=2.3 \mathrm{~Hz}$ ). The ring $\mathrm{C}$ protons exhibited an $\mathrm{ABX}$ pattern $(6.80, \mathrm{~d}, J=1.8 \mathrm{~Hz}, \mathrm{H}-2$ '; $\delta 6.85, \mathrm{~d}, J=8.2$ $\mathrm{Hz} ; \delta 6.76$, dd, $J=8.2,1.8 \mathrm{~Hz}$ ), and the remaining hydroxyl groups were placed at C3' and C-4'. The configuration of the double bond was established as $E$ from the distinctive chemical shift of the H-9 resonance ( $\delta$ 7.58) (Masterova et al., 1991).

Isolates 1-5Ac, as well as ten known compounds re-isolated in this work (6-15) were screened for cyclo-oxygenase-2 (COX-2) inhibitory activity. Two COX isoenzymespecific inhibitors were used as positive controls, namely SC-560 and DuP-697 (Cayman Chemical Company, 2011), and these compounds were shown to be selective for COX-1 and COX-2 isoenzymes in the assay system that was utilised (Figure 2 and Table 3). Compounds 5Ac, 6, 7 and 10, showed significant COX-2 inhibitory activity when screened at $10 \mu \mathrm{M}$. The compounds which showed inhibitory activity for COX-2 were screened against cyclooxygenase-1 (COX-1) to measure their selectivity for the COX-2 enzyme. Compounds 6 and 7 were found to be nonspecific inhibitors of both the COX-1 and COX-2 enzyme during these studies. Compound 10, (E)-3-(3',4'-dihydroxybenzylidene)-7-hydroxy-5-methoxychroman-4one, however, was completely selective for COX-2 at a concentration of $10 \mu \mathrm{M}$, and had an $\mathrm{IC}_{50}$ for COX-2 of $2.87 \mu \mathrm{M} \pm 1.2$. Compound 5Ac was partially selective, inhibiting COX-1 with an $\mathrm{IC}_{50}$ of $2.56 \mu \mathrm{M} \pm 1.2$ and $\mathrm{COX}-2$ with an $\mathrm{IC}_{50}$ of $1.12 \mu \mathrm{M}$ $\pm 0.56 \mu \mathrm{M}$. The COX-2 specific inhibitor DuP-697 had an $\mathrm{IC}_{50}$ value of $40 \mathrm{nM}$, which is substantially lower than those shown above. However, the isolates show $\mathrm{IC}_{50}$ 
values which are within the range of widely used and non-selective inhibitors such asparacetamol (acetaminophen) ( $\mathrm{IC}_{50} 26 \mu \mathrm{M}$ for COX-2) (Hinz et al., 2008).. It can therefore be concluded that the isolates above could be therapeutically valuable and that compound $\mathbf{1 0}$ could be developed into a clinically relevant and COX-2 specific inhibitor.

\section{Experimental}

\subsection{General Experimental Procedures}

1D and 2D NMR spectra were recorded in $\mathrm{CDCl}_{3}$ and $\mathrm{CD}_{3} \mathrm{OD}$ on a $500 \mathrm{MHz}$ Bruker AVANCE NMR instrument at room temperature. Chemical shifts $(\delta)$ are expressed in $\mathrm{ppm}$ and were referenced to the solvent references at 7.26 and $77.23 \mathrm{ppm}$ for $\mathrm{CDCl}_{3}, 4.87$ and $49.15 \mathrm{ppm}$ for $\mathrm{CD}_{3} \mathrm{OD}$ for ${ }^{1} \mathrm{H} \mathrm{NMR}$ and ${ }^{13} \mathrm{C}$ NMR respectively. ESI mass spectra were recorded on a Bruker MicroToF mass spectrometer using an Agilent 1100 HPLC to introduce samples (University of Oxford), optical rotations were determined in $\mathrm{CHCl}_{3}$ on a JASCO P-1020 polarimeter (University of Surrey), IR spectra were recorded using a Perkin-Elmer 2000 spectrometer, and UV and CD spectra were obtained on a Chirascan spectropolarimeter at room temperature using a $1 \mathrm{~cm}$ cell in $\mathrm{MeOH}$.

\subsection{Plant Material}

Ledebouria ovatifolia (Bak.) Jessop bulbs (1.0 kg) were purchased from the medicinal plant market in Johannesburg, Gauteng in November 2007 and a flowering voucher retained ( $N$. Crouch 1278, NH). Bulbs of cultivated Ledebouria socialis (Bak.) Jessop (silver-leaved form)(1.0 kg) were harvested during January 2007 and a voucher retained (N. Crouch 1118, NH). Plant materials were identified by Professor N. Crouch of the South African National Biodiversity Institute (SANBI).

\subsection{Extraction and Isolation of Compounds}

The air-dried bulbs of $L$. socialis were chopped and extracted using dichloromethane and methanol successively on a shaker for 48 hours. Evaporation of the solvents in vacuo yielded dichloromethane $(1.47 \mathrm{~g})$ and methanol $(7.50 \mathrm{~g})$ extracts. Column chromatography of both extracts was performed over silica gel (Merck 9385) using a $5 \mathrm{~cm}$ diameter gravity column, collecting fractions $(75 \mathrm{ml}$ each) using a hexane/dichloromethane stepwise gradient followed by a dichloromethane/ methanol 
stepwise gradient. Preparative TLC on $0.2 \mathrm{~mm}$ silica gel, aluminium backed plates (Merck Art. 5554) was subsequently used. Compounds were detected using a UVlamp or, where necessary, a section of the plate was developed using anisaldehyde spray reagent, with subsequent heating. Final purification was undertaken using a 1 $\mathrm{cm}$ diameter column. The dichloromethane extract yielded compound $\mathbf{1}$ (Fraction 189-198, $53.9 \mathrm{mg}$, followed by preparative TLC in 10\% EtOAc/DCM, eluted twice) as well as known compounds (R)-5-hydroxy-7,2',3',4'-tetramethoxyspiro\{2H-1benzopyran-3-(4H)-9-bicyclo[4.2.0]octa[1,3,5]-triene\}-4-one (34.7 mg), phytol and stigmasterol. The methanol extract yielded only the known compound polybotrin (1.8 $\mathrm{mg})$.

The bulbs of L. ovatifolia were extracted using dichloromethane, ethyl acetate and methanol successively on a shaker for 48 hours. After evaporation of the solvents in vacuo the following extracts were obtained: dichloromethane (19.65 g), ethyl acetate (11.56 g) and methanol (54.95 g). Column chromatography over silica gel (Merck 9385) using a $5 \mathrm{~cm}$ diameter gravity column, collecting fractions (75 $\mathrm{ml}$ each) using a hexane/dichloromethane stepwise gradient followed by a dichloromethane/ methanol stepwise gradient, was used to separate the constituents. Final purification was undertaken using a $1 \mathrm{~cm}$ diameter column. The dichloromethane extract yielded compound 2 (Fractions 140-145, $20 \mathrm{mg}, 98 \% \mathrm{CH}_{2} \mathrm{Cl}_{2} / 2 \%$ diethyl ether, compound 3 (Fraction 237-248, $2.1 \mathrm{mg}, 20 \%$ diethyl ether/ $80 \% \mathrm{CH}_{2} \mathrm{Cl}_{2}$ ), and compound 4 (Fractions 140-145, 6.7mg, 90\% $\mathrm{CH}_{2} \mathrm{Cl}_{2} / 10 \%$ diethyl ether) as well as known compounds $(R)$-5,7-dihydroxy-3-(4'-hydroxybenzyl)chroman-4-one (10.2 mg), $(E)$ 4,4'-dihydroxy-2',6'-dimethoxychalcone $(6.3 \mathrm{mg})$, scillascillin $(1.3 \mathrm{mg}), \quad$ 1,6dihydroxy-3-methoxy-8-methyl-9H-xanthen-9-one (2.2 mg), $(R)$-4',5,7-trihydroxy-3'methoxyspiro $\{2 H$-1-benzopyran-3(4H)-9-bicyclo[4.2.0]octa[1,3,5]triene $\}$-4-one $(2.6$ $\mathrm{mg}), \quad(R)$-3', 5,7-trihydroxy-4'-methoxyspiro\{2H-1-benzopyran-3(4H)-9bicyclo[4.2.0]octa[1,3,5]triene $\}-4-o n e \quad(4.5 \quad \mathrm{mg}), \quad(R)$-5,7-dihydroxy-3-(4'methoxybenzyl)chroman-4-one (7.3 mg), eucomol (4.4 mg), $(R)$-7-hydroxy-3-(4'hydroxybenzyl)-5-methoxychroman-4-one $(6.9 \mathrm{mg})$, coniferaldehyde $(0.5 \mathrm{mg})$ and chondrillasterol $(18.7 \mathrm{mg})$. The ethyl acetate extract yielded compound 5 (Fraction 61-75, $3 \mathrm{mg}, 100 \% \mathrm{CH}_{2} \mathrm{Cl}_{2}$ ) and known compounds drimiopsin $\mathrm{C}$ (12.8 $\mathrm{mg}$ ), norlichexanthone (2 mg), 22-acetoxy-15-deoxoeucosterol (6 mg), (R)-(3-(3',4'dihydroxybenzyl)-5,7-dihydroxychroman-4-one (7.8 mg), 4'-demethyl-5-O-methyl- 
dihydroeucomin $\quad(13.3 \quad \mathrm{mg}), \quad(R)-3-(3 ', 4$ '-dihydroxybenzyl)-7-hydroxy-5methoxychroman-4-one (370 mg) (E)-3-(3',4'-dihydroxybenzylidene)-7-hydroxy-5methoxychroman-4-one (7.5 mg), p-anisic aldehyde $(5.2 \mathrm{mg})$ and 4hydroxyphenylethanol $(1.1 \mathrm{mg})$. The methanol extract yielded only the known compound polybotrin $(7.0 \mathrm{mg})$.

\subsection{1 (R)-2',5-dihydroxy-3',4',7-trimethoxyspiro\{2H-1-benzopyran-3-(4H)-9-} bicyclo[4.2.0]octa[1,3,5]triene]-4-one (1)

Yellow oil; $[\alpha]_{\mathrm{D}}^{23.6}+40\left(c 0.005, \mathrm{CHCl}_{3}\right) ; \mathrm{CD}$ data $(\mathrm{c} 0.001, \mathrm{MeOH}) 297 \mathrm{~nm}(+1.51)$, $340 \mathrm{~nm}$ (-1.75); UV $\left(\mathrm{CDCl}_{3}\right) \lambda_{\max } 240,290 \mathrm{~nm}$; IR $v_{\max }(\mathrm{NaCl}) \mathrm{cm}^{-1} 3455,2959$, 2929, 2860, 1737, 1462, 1380, 1242, 1174, 1078, 665; ${ }^{1} \mathrm{H}\left(500 \mathrm{MHz}, \mathrm{CDCl}_{3}\right)$ and ${ }^{13} \mathrm{C}$ NMR (125 MHz, $\mathrm{CDCl}_{3}$ ) spectroscopic data, see Table 1; HRESIMS m/z 381.0948 $[\mathrm{M}+\mathrm{Na}]^{+}$(calc. for $\mathrm{C}_{19} \mathrm{H}_{18} \mathrm{O}_{7} \mathrm{Na} 381.0945$ ).

\subsection{2 (2R,3R)-2,5-diacetoxy-7-methoxyspiro[2H-1-benzopyran-3(4H), 5'(6'H)- cyclobuta[f][1,3]benzodioxol]-4-one $(2(\boldsymbol{R})$}

Clear oil; $[\alpha]_{\mathrm{D}}^{23.6}-172$ (c 0.006, $\left.\mathrm{CHCl}_{3}\right)$; CD data (c 0.001, $\left.\mathrm{MeOH}\right) 275 \mathrm{~nm}(-2.22)$, $300 \mathrm{~nm}$ (-6.80); UV $\left(\mathrm{CDCl}_{3}\right) \lambda_{\max } 290 \mathrm{~nm}$; IR $v_{\max }(\mathrm{NaCl}) \mathrm{cm}^{-1}$ 2975, 2927, 2898, 1758, 1649, 1624, 1571, 1455, 1381, 1317, 1271, 1233, 1152, 1088, 1048, 880, 805, 739, 666; ${ }^{1} \mathrm{H}\left(500 \mathrm{MHz}, \mathrm{CDCl}_{3}\right)$ and ${ }^{13} \mathrm{C} \mathrm{NMR}\left(125 \mathrm{MHz}, \mathrm{CDCl}_{3}\right)$ spectroscopic data, see Table 1; HRESIMS m/z $449.0843[\mathrm{M}+\mathrm{Na}]^{+}$(calc. for $\mathrm{C}_{22} \mathrm{H}_{18} \mathrm{O}_{9} \mathrm{Na} 449.0843$ ).

\subsection{3 (2S,3R)-2, 5-diacetoxy-7-methoxyspiro[2H-1-benzopyran-3(4H), 5'(6'H)- cyclobuta[f][1,3]benzodioxol]-4-one (2(S))}

Clear oil; $[\alpha]_{\mathrm{D}}^{23.6}+173\left(\right.$ c $\left.0.010, \mathrm{CHCl}_{3}\right)$; $\mathrm{CD}$ data $(\mathrm{c} 0.001, \mathrm{MeOH}) 275 \mathrm{~nm}(-1.68)$, $307 \mathrm{~nm}(+8.92)$; UV $\left(\mathrm{CDCl}_{3}\right) \lambda_{\max } 300,270 \mathrm{~nm}$; IR $v_{\max }(\mathrm{NaCl}) \mathrm{cm}^{-1} 2922,2850$, 1758, 1686, 1619, 1570, 1457, 1369, 1302, 1269, 1233, 1194, 1152, 1106, 1036, 1007, 971, 937, 886, 846, 811, 754, 666; ${ }^{1} \mathrm{H}\left(500 \mathrm{MHz}, \mathrm{CDCl}_{3}\right)$ and ${ }^{13} \mathrm{C} \mathrm{NMR}(125$ $\left.\mathrm{MHz}, \mathrm{CDCl}_{3}\right)$ spectroscopic data, see Table 1; HRESIMS m/z $449.0842[\mathrm{M}+\mathrm{Na}]^{+}$ (calc. for $\mathrm{C}_{22} \mathrm{H}_{18} \mathrm{O}_{9} \mathrm{Na} 449.0843$ ).

\subsubsection{Acetylation of 2-hydroxy-7-O-methylscillascillin (2)}

Compound 2 (20 mg) was dissolved in pyridine $(3 \mathrm{ml})$, acetic anhydride $(3 \mathrm{ml})$ was added and the mixture was left to stand for $12 \mathrm{~h}$. $\mathrm{MeOH}(2 \times 5 \mathrm{ml})$ was added and 
solvent was removed under vacuum. The residue was subsequently purified using preparative TLC (40\% hexane: $58 \% \mathrm{CH}_{2} \mathrm{Cl}_{2}: 2 \%$ diethyl ether) to yield $\mathbf{2}(\boldsymbol{R})(6 \mathrm{mg})$ and $2(S)(10 \mathrm{mg})$.

\subsubsection{4',4-Dihydroxy-2',6'-dimethoxydihydrochalcone (3)}

White amorphous powder; UV $\left(\mathrm{CDCl}_{3}\right) \lambda_{\max } 280 \mathrm{~nm}$; IR $v_{\max }(\mathrm{NaCl}) \mathrm{cm}^{-1} 3377,2953$, 2924, 2854, 2356, 2336, 1736, 1676, 1598, 1513, 1463, 1370, 1247, 1220, 1166, 1126, 1032, 996, 827, 756; ${ }^{1} \mathrm{H}$ NMR $\left(500 \mathrm{MHz}, \mathrm{CDCl}_{3}\right) \delta 7.07(2 \mathrm{H}, \mathrm{d}, J=8.5 \mathrm{~Hz}$, 2/6), $\delta 6.73(2 \mathrm{H}, \mathrm{d}, J=8.5 \mathrm{~Hz}, 3 / 5), \delta 6.02\left(2 \mathrm{H}, \mathrm{s}, 3^{\prime} / 5^{\prime}\right), \delta 3.71\left(3 \mathrm{H}, \mathrm{s}, 2^{\prime} / 6{ }^{\prime}-\mathrm{OCH}_{3}\right), \delta$ $3.01(2 \mathrm{H}, \mathrm{t}, 7.7 \mathrm{~Hz}, \alpha), \delta 2.92(2 \mathrm{H}, \mathrm{t}, 7.7 \mathrm{~Hz}, \beta)$ and ${ }^{13} \mathrm{C} \mathrm{NMR}\left(125 \mathrm{MHz}, \mathrm{CDCl}_{3}\right), \delta$ $203.1(\mathrm{C}=\mathrm{O}), \delta 158.7\left(\mathrm{C}, 2^{\prime} / 6^{\prime}\right), \delta 158.7$ (C, 4'), $\delta 153.6(\mathrm{C}, 4), \delta 133.7(\mathrm{C}, 1), \delta$ 129.9 (2-CH, 2/6), $\delta 112.8$ (C, 1'), $\delta 115.5$ (2-CH, 3/5), $\delta 92.3$ (2-CH, 3'/5'), $\delta 56.2$ $\left(\mathrm{CH}_{3}, 2 \text { '/6'-OCH}\right)_{3}, \delta 46.9\left(\mathrm{CH}_{2}, \alpha\right), \delta 29.4\left(\mathrm{CH}_{2}, \beta\right)$; HRESIMS $m / z, 325.1045$ $[\mathrm{M}+\mathrm{Na}]^{+}$(calc. for $\mathrm{C}_{17} \mathrm{H}_{18} \mathrm{O}_{5} \mathrm{Na} 325.1046$ ).

\subsubsection{1,6-dihydroxy-2,3,5-trimethoxy-8-methyl-9H-xanthen-9-one (4)}

Yellow amorphous powder; UV $\left(\mathrm{CDCl}_{3}\right) \lambda_{\max } 310,250 \mathrm{~nm}$; IR $v_{\max }(\mathrm{NaCl}) \mathrm{cm}^{-1} 3417$, 2922, 2850, 2101, 1643, 1311, 1454, 1511, 1209, 1181, 1153, 1123, 1072, 1035, 987;

${ }^{1} \mathrm{H}$ NMR $\left(500 \mathrm{MHz}, \mathrm{CDCl}_{3}\right)$ spectroscopic data $\delta 13.26(1 \mathrm{H}, \mathrm{s}, 1-\mathrm{OH}), \delta 6.75(1 \mathrm{H}, \mathrm{s}$, 7), $\delta 6.46(1 \mathrm{H}, \mathrm{s}, 4), \delta 6.24(1 \mathrm{H}, \mathrm{s}, 6-\mathrm{OH}), \delta 4.05(3 \mathrm{H}, \mathrm{s}, 5-\mathrm{OMe}), \delta 3.97$ (3H, s, 3$\mathrm{OMe}), \delta 3.91(3 \mathrm{H}, \mathrm{s}, 2-\mathrm{OMe}), \delta 2.80\left(3 \mathrm{H}, \mathrm{s}, 8-\mathrm{CH}_{3}\right) ;{ }^{13} \mathrm{C} \mathrm{NMR}\left(125 \mathrm{MHz}, \mathrm{CDCl}_{3}\right)$ spectroscopic data $\delta 182.9(\mathrm{C}, 9) ; \delta 159.4(\mathrm{C}, 3), \delta 155.0(\mathrm{C}, 1), \delta 153.2(\mathrm{C}, 6), \delta$ $152.3(\mathrm{C}, 4 \mathrm{a}), \delta 151.2(\mathrm{C}, 5 \mathrm{a}), \delta 138.5(\mathrm{C}, 8), \delta 132.2(\mathrm{C}, 5 / 2), \delta 114.9(\mathrm{CH}, 7), \delta$ $104.5(\mathrm{C}, 1 \mathrm{a}), \delta 90.1(\mathrm{CH}, 4), \delta 62.1\left(\mathrm{CH}_{3}, 2-\mathrm{OMe}\right), \delta 61.1\left(\mathrm{CH}_{3}, 3-\mathrm{OMe}\right), \delta 56.5$ $\left(\mathrm{CH}_{3}, 5-\mathrm{OMe}\right), \delta 23.4\left(\mathrm{CH}_{3}, 8-\mathrm{CH}_{3}\right), \mathrm{HRESIMS} \mathrm{m} / \mathrm{z} 355.0787[\mathrm{M}+\mathrm{Na}]^{+}$(calc. for $\left.\mathrm{C}_{17} \mathrm{H}_{16} \mathrm{O}_{7} \mathrm{Na} 355.0788\right)$.

\subsection{6 (E)-3-(3',4'-dihydroxybenzylidene)-5-acetoxy-7-hydroxychroman-4-one}

(ovatifolionone acetate) (5Ac) Yellow amorphous powder; $\mathrm{UV}\left(\mathrm{CDCl}_{3}\right) \lambda_{\max } 280,360$ $\mathrm{nm} ; \mathrm{IR} v_{\max }(\mathrm{NaCl}) \mathrm{cm}^{-1} 3582,3415,2957,2920,2361,2336$ 1745, 1638, 1512,1461, 1447, 1370, 1259, 1202, 1162, 1115; ${ }^{1} \mathrm{H}$ NMR (500 MHz, $\left.\mathrm{CDCl}_{3}\right)$ and ${ }^{13} \mathrm{C} \mathrm{NMR} \mathrm{(125}$ $\mathrm{MHz}, \mathrm{CDCl}_{3}$ ) spectroscopic data for 5Ac, see Table 1; HRESIMS m/z 299.0553 [MOAc] ${ }^{-}$(calc. for $\mathrm{C}_{16} \mathrm{H}_{11} \mathrm{O}_{6} 299.0561$ ). 
3.3.6.1 Acetylation of (E)-3-(3,4-dihydroxybenzylidene)-5,7-dihydroxychroman-4-one (5)

Compound 5 (3 mg) was acetylated using the method described in section 3.3.4.1 and purified using normal phase column chromatography $\left(100 \% \mathrm{CH}_{2} \mathrm{Cl}_{2}\right)$ to yield Compound 5Ac (1.8 mg).

\subsection{Assay for inhibition of COX activity}

Assays were performed in a 96-well plate with purified COX-1 from ram seminal vesicles (Sigma Aldrich UK, C0733, >40000 units/mg) or human purified COX-2 (Sigma Aldrich UK, C0858, >8000 units/mg ). COX enzymes were used after a 1/3 dilution into buffer $(0.1 \mathrm{M}$ Tris. $\mathrm{HCl}, \mathrm{pH} 8)$ and $5 \mu \mathrm{l}$ of the diluted solution was used in a $200 \mu$ total volume.

Cyclooxygenase inhibition was assayed using the Cayman Fluorescence activity kit (C) guidelines (Cayman Chemical Company, 2011) measured by the conversion of $\mathrm{PGG}_{2}$ to $\mathrm{PGH}_{2}$ via the fluorescence of an additive called Amplex Red (Cayman Chemical Co., A1111, $5 \mathrm{mg}$, final assay concentration of $100 \mu \mathrm{M}$ ). Inhibition of COX refers to a reduction of $\mathrm{PGH}_{2}$ formation, demonstrated by a reduction in fluorescence, in comparison to a non-inhibitor control (Batchelor et al., 2003). DuP-697 (Cayman Chemical Co., 760158, $5 \mathrm{mg}, 304 \mathrm{nM}$ final assay concentration) and SC-560 (Cayman Chemical Co., 70340, $5 \mathrm{mg}, 354 \mathrm{nM}$ final assay concentration) were used as positive inhibitor controls for COX-1 and COX-2 respectively (Cayman Chemical Company, 2011).

Other additives included the substrate, arachidonic acid (Sigma Aldrich, A9673, 10 $\mathrm{mg}, 100 \mu \mathrm{M}$ final assay concentration), the cofactor hematin (Sigma Aldrich, H3281, $250 \mathrm{mg}, 100 \mu \mathrm{M}$ final assay concentration) and buffer (0.1 M, Tris. HCl, pH 8).

The study was performed on a SpectraMax Gemini XS (Molecular Devices) wellplate fluorimeter using SoftMax Pro software. The fluorimeter takes 96-well plates and was set to read at $535 \mathrm{~nm}$ and $595 \mathrm{~nm}$ excitation and emission wavelengths, with a cut-off filter at $550 \mathrm{~nm}$, set manually. Automix was turned on for two seconds before each run. The readings were taken in the 'normal' range (5), at medium sensitivity when using the COX-2 enzyme and low sensitivity when using the COX-1 
enzyme. Each assay was run for 300 seconds with intervals ranging from 3-10 seconds depending on the number of wells measured.

\subsubsection{Sample Preparation}

Samples were dissolved to make a $20 \mathrm{mM}$ solution in ethanol, of which $1 \mu \mathrm{l}$ was diluted with $100 \mu \mathrm{l}$ buffer to give a $200 \mu \mathrm{M}$ solution. $10 \mu \mathrm{l}$ of the latter solution was used in a total assay volume of $200 \mu \mathrm{l}$ to give a final concentration of $10 \mu \mathrm{M}$. Compounds were tested at a screening concentration of $10 \mu \mathrm{M}$ and compounds showing activity and no inhibitory activity for $\mathrm{COX}-1$ at this concentration were subjected to $\mathrm{IC}_{50}$ determination.

\subsection{Computational methods}

The conformational searches for Compounds $2(R)$ and $2(S)$ were carried out at the molecular mechanics level of theory employing MMFF force field incorporated in the Spartan08 (Wavefunction, Irvine, CA) software package. Global minimum conformers were subjected to TDDFT calculations using a B3LYP method at 6-31G (d, f) level built in to Gaussian09 software (Frisch, et al., 2010). The simulated ECD curves were UV-corrected where necessary and compared to the experimental ECD curves.

\section{Supplementary information}

Supplementary data associated with this article can be found, in the online version, XXXXXXXXXXX.

\section{Acknowledgements}

$\mathrm{CW}$ wishes to gratefully acknowledge a PhD studentship from the Marion Redfearn Trust from the University of Surrey.

\section{References}

Abegaz, B.M., Mutanyatta-Comar, J., Nindi, M., 2007, Naturally occurring homoisoflavonoids: phytochemistry, biological activities and synthesis, Nat. Prod. Commun., 2, 4, 475-498 
Adinolfi, M., Barone, G., Belardini, M., Lanzetta, R., Laonigro, G., Parrilli, M., 1985, Homoisoflavanones from Muscari comosum bulbs, Phytochemistry, 24, 10, 2423 2426

Adinolfi, M., Corsaro, M.M., Lanzetta R., Laonigro, G., Mangoni, L., Parrilli, M., 1987, Ten homoisoflavanones from two Muscari species, Phytochemistry, 26, 1, 285 290

Adinolfi, M., Barone, G., Giordano, F., Lanzetta, R., Parrilli, M., 1990, Absolute configuration of benzocyclobutene homoisoflavanones from Muscari species, Tetrahedron, 46, 18, 6565-6574

Aghoramurthy, K., Seshadri, T.R., 1953, Chemical investigation of Indian lichens. XV. A species of Parmelia containing lichexanthone, J. Sci. Ind. Res. India, 12B, 7376

Amschler, G., Frahm, A.W., Muller-Doblies, D., Muller-Doblies, U., 1997, Constituents of Veltheimia viridifolia. Part 2. Spirocyclic norterpenes from the bulbs of Veltheimia viridifolia, Phytochemistry, 47, 3, 429-436

Bangani, V., Crouch, N.R., Mulholland, D.A., 1999, Homoisoflavonones and stillbenoids from Scilla nervosa, Phytochemistry, 51, 947-951

Batchelor, R., Johnson, I., Beecham, J., Molecular probes ®, 2003, A fluorimetric assay for cyclooxygenase enzymes, presented at the Society for Biomolecular Screening: Portland, Oregon, September, 21-25, available at http://probes.invitrogen.com/media/publications/355.pdf, [accessed April 2012]

Bergmann, W., Feeney, R.J., 1948, Contributions to the study of marine products XXI. Chondrillasterol, J. Org. Chem., 13, 738-741

Bohler, D., Tamm, C., 1967, The homoisoflavanones, a new class of natural product. Isolation and structure of eucomin and eucomol, Tetrahedron Lett., 36, 3479-3483

Burgueno-Tapia, E., Hernandez-Carlos, B., Joseph-Nathan, P. 2006, DFT, solution, and crystal conformation of eremophilanolides, J. Mol. Struct. 825, 115-123

Cayman fluorescence COX activity kit information booklet, (C) 10/03/11 Cayman Chemical Company, Ann Arbor, MI, USA

Cipollone, F., Cicolini, G., Bucci, M., 2008, Cyclooxygenase and prostaglandin synthases in atherosclerosis: Recent insights and future perspectives, Pharmacol. Therapeut., 118, 161-180 
Della Loggia, R., Del Negro, P., Tubaro, A., Barone, G., Parrilli, M., 1989, Homoisoflavanones as anti-inflammatory principles of Muscari comosum, Planta Med., 55, 587-588

Devlin, F. J., Stephens, P.J., Figadere, B., 2009, Determination of the absolute configuration of the natural product klaivanolide via density functional calculations of vibrational circular dichroism (VCD), Chirality, 21, 48-53

Felippe, L.G., Batista Jr., J.M., Baldoqui, DC., Nascimenta, IR., Kato, MJ., He, Y., Nafie, LA. And Furlan, M., 2012, VCD to determine absolute configuration of natural product molecules: secolignans from Peperomia blanda, Org. Biomol. Chem. 10, 4208-4214

Finckh, R.E., Tamm, C., 1970, The homo-isoflavanones III- isolation and structure of punctatin, 3,9-dihydropunctatin, 4'-O-methyl-3,9-dihydropunctatin, 4'demethyleucomin and 4'-demethyl-5- $O$-methyl-3,9-dihydro-eucomin, Experientia, 26,472

Frisch, M. J.; Trucks, G.W.; Schlegel, H. B.; Scuseria, G. E.; Robb, M.A.; Cheeseman, J.R.; Scalmani, G.;Barone, V.;Mennucci, B.; Petersson, G.A.; Nakatsuji, H.; Caricato, M.; Li, X.; Hratchian, H.P.;Izmaylov, A.F.;Bloino, J.;Zheng, G.;Sonnenberg, J.L.;Hada, M.; Ehara, M.; Toyota, K.; Fukuda, R.; Hasegawa, J.; Ishida, M.; Nakajima, T.; Honda, Y.;Kitao, O.; Nakai, H.;Vreven, T.; Montgomery, Jr. J. A.; Peralta, J. E.; Ogliaro, F.; Bearpark, M.; Heyd, J. J.; Brothers, E.; Kudin, K. N.; Staroverov, V. N.; Keith, T.; Kobayashi, R.; Normand, J.; Raghavachari, K.; Rendell, A.; Burant, J. C.; Iyengar, S. S.; Tomasi, J.; Cossi, M.; Rega, N.; Millam, J. M.; Klene, M.; Knox, J. E.; Cross, J. B.; Bakken, V.; Adamo, C.; Jaramillo, J.; Gomperts, R.; Stratmann, R. E.; Yazyev, O.; Austin, A. J.; Cammi, R.; Pomelli, C.; Ochterski, J. W.; Martin, R. L.; Morokuma, K.; Zakrzewski, V. G.; Voth, G. A.; Salvador, P.; Dannenberg, J. J.; Dapprich, S.; Daniels, A. D.; Farkas, O.; Foresman, J. B.; Ortiz, J. V.; Cioslowski, J.; Fox, D. J.; Gaussian, Inc., Wallingford CT, Gaussian 09, Revision B.01, 2010.

Gerstner, J., 1938, A preliminary check list of Zulu names of plants, with short notes, Bantu Studies 12, 4, 321-342

Gharbo, S.A., Saleh, M.R.I., Abdel Salim, N., 1970, Phytochemical investigation of Lingustrum ovalifolium, J. Pharm. Sci. UAR, 11, 1, 113-121 
Giardiello, F.M., Offerhaus, G.J.A., DuBois, R.N., 1995. The role of nonsteroidal anti-inflammatory drugs in colorectal cancer prevention, Eur. J. Cancer 31, 10711076

Gottlieb, O.R., Koketsu, M., Lannes M.L., Moreira, A., Taveira M.M, 1970,

Chemistry of Brazilian Myrtaceae. II. Essential oils of Pseudocaryophyllus jaccoudii and Calyptranthes species, A. Ac. Br. Ciên, 42, 143-146

Heller, W., Andermatt, P., Schaad, W.A., Tamm, C., 1976, Homoisoflavanones IV. New constituents of the eucomin series from Eucomis bicolor, Helv. Chim. Acta, 59, 6, 2048-2058

Hinz, B., Cheremina, O., Brune, K., 2008, Acetaminophen (paracetamol) is a selective cyclooxygenase-2 inhibitor in man, FASEB J., 22, 383-390

Hutchings, A., Scott, A.H., Lewis, G., Cunningham, A.B., 1996, Zulu medicinal plants. An inventory, University of Natal Press: Pietermaritzburg, 38-44

Jessop, J.P., 1970, Studies in the bulbous Liliaceae: 1. Scilla, Schizocarphus and Ledebouria, S. Afr. J. Bot, 36, 4, 233-266

Kato, A., Kato, N., Adachi, I., Hollinshead, J., Fleet, G.W.J., Kuriyama, C., Ikeda, K., Asano, N., Nash, R.J., 2007, Isolation of glycosidase-inhibiting hyacinthacines and related alkaloids from Scilla socialis, J. Nat. Prod., 70, 6, 993-997

Kawasaki, T., Komori, T. and Kouno, I., 1973, Zur struktur der neuen typen homoisoflavanone aus bulben von Scilla scilloides Druce, Tetrahedron Lett., 46, 4569

Levy, G.N., 1997. Prostaglandin H synthases, nonsteroidal anti-inflammatory drugs, and colon cancer, FASEB J., 11, 234-247

Masterova, I., Suchy, V., Uhrin, D., Ubik, K., Grancaiova, Z., Bobovnicky, B., 1991, Homoisoflavanones and other constituents from Muscari racemosum,

Phytochemistry, 30, 2, 713-714

McMaster, W.J., Scott, A.I., Tripett, S., 1960, Metabolic products of Penicillium patulum, J. Chem. Soc., 4628-4631

Mulholland, D.A., Koorbanally, C., Crouch, N., Sandor, P., 2004, Xanthones from Drimiopsis maculata, J. Nat. Prod., 67, 10, 1726-1738

Mutanyatta, J., Matapa, B.G., Shushu, D.D., Abegaz, B.M., 2003, Homoisoflavonoids and xanthones from the tubers of wild and in vitro regenerated Ledebouria graminifolia and cytotoxic activities of some of the homoisoflavanoids, Phytochemistry, 62, 5, 797-804 
Ngamga, D., Bipa, J., Lebatha, P., Hiza, C., Mutanyatta, J., Bezabih, M.T., Tane, P., Abegaz, B.M., 2008, Chemical constituents from Drimiopsis barteri and D. burkei, Nat. Prod. Comm., 3, 5, 769-777

O’Banion, M.K., Winn, V.D., Young, D.A., 1992. cDNA cloning and functional activity of a glucocorticoid-regulated inflammatory cyclooxygenase. Proc. Natl. Acad. Sci. USA 89, 4888-4892

Pohl, T., Crouch, N.R., Mulholland, D.A., 2000, Southern African Hyacinthaceae: chemistry, bioactivity and ethnobotany, Curr. Org. Chem., 4, 12, 1287-1324

Pohl, T., Koorbanally, C., Crouch, N.R., Mulholland D.A., 2001, Secondary metabolites of Scilla plumbea, Ledebouria cooperi and Ledebouria ovatifolia (Hyacinthaceae), Biochem. Syst. Ecol., 29, 8, 857-860

Seikel, M.K., Hostettler, F.D., Niemann, G.J., 1971, Fagaceae. Phenolics of Quercus rubra wood, Phytochemistry, 10, 9, 2249-2251

Smith, W.L., Dewitt, D.L., Garavito, M., 2000, Cyclooxygenase: Structural, cellular and molecular biology, Annu. Rev. Biochem., 69, 145-182

Speta, F., 1998, Hyacinthaceae. In: Kubitzki, K. (Ed.) The families and genera of vascular plants. Vol. 3. Springer, Berlin, 261-285

Steyn, D.G., 1936, Recent investigations into the toxicity of known and unknown poisonous plants in the Union of South Africa, Onderst. J. Vet. Sci. Anim. Ind., 7, 1, 169-178

Sun, S., Watanabe, S., Saito, T., 1989, Chalcones from Humulus lupulus, Phytochemistry, 28, 6, 1776-1777

Van der Walt, S.J., Steyn, D.G., 1941, Recent investigations into the toxicity of known and unknown poisonous plants in the Union of South Africa XII, Onderst. J. Vet. Sci. Anim. Ind., 17, 1\&2, 211-223

Venter, S., 2008, Synopsis of the genus Ledebouria Roth (Hyacinthaceae) in South Africa, Herbertia, 62, 85-155.

Zou, K., Komatsu, K., Zhu, S., 2007, A novel compound from Hedysarum polybotrys, J. Asian. Nat. Prod. Res., 9, 6-8, 699-703 


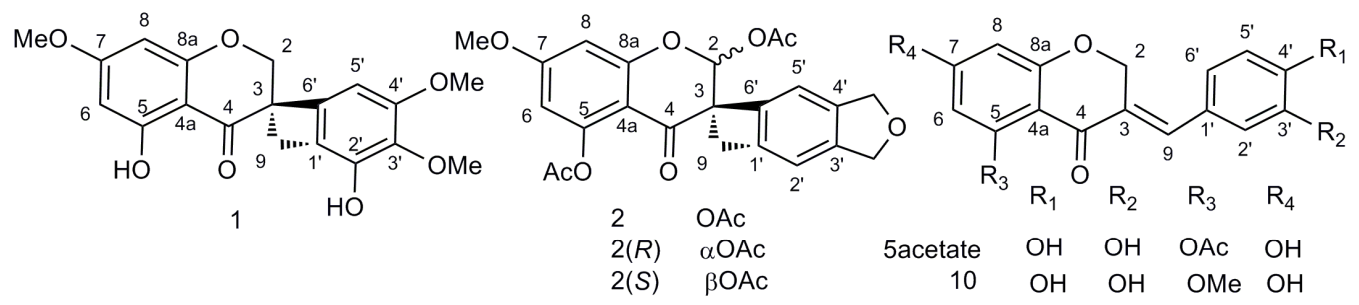<smiles>[R]c1ccc(CC2(C)COc3cc(O)cc(O)c3C2=O)c(C)c1</smiles>

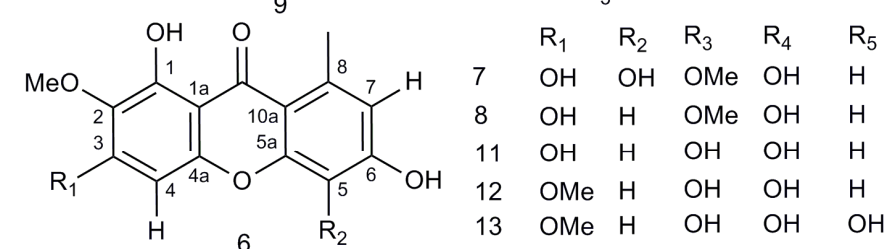

$R_{1} \quad R_{2}$

$4 \mathrm{MeO} \mathrm{MeO}$

$6 \mathrm{OH} \mathrm{H}$

Figure 1. Compounds isolated from Ledebouria socialis and Ledebouria ovatifolia and screened in COX-1 and COX-2 assay 


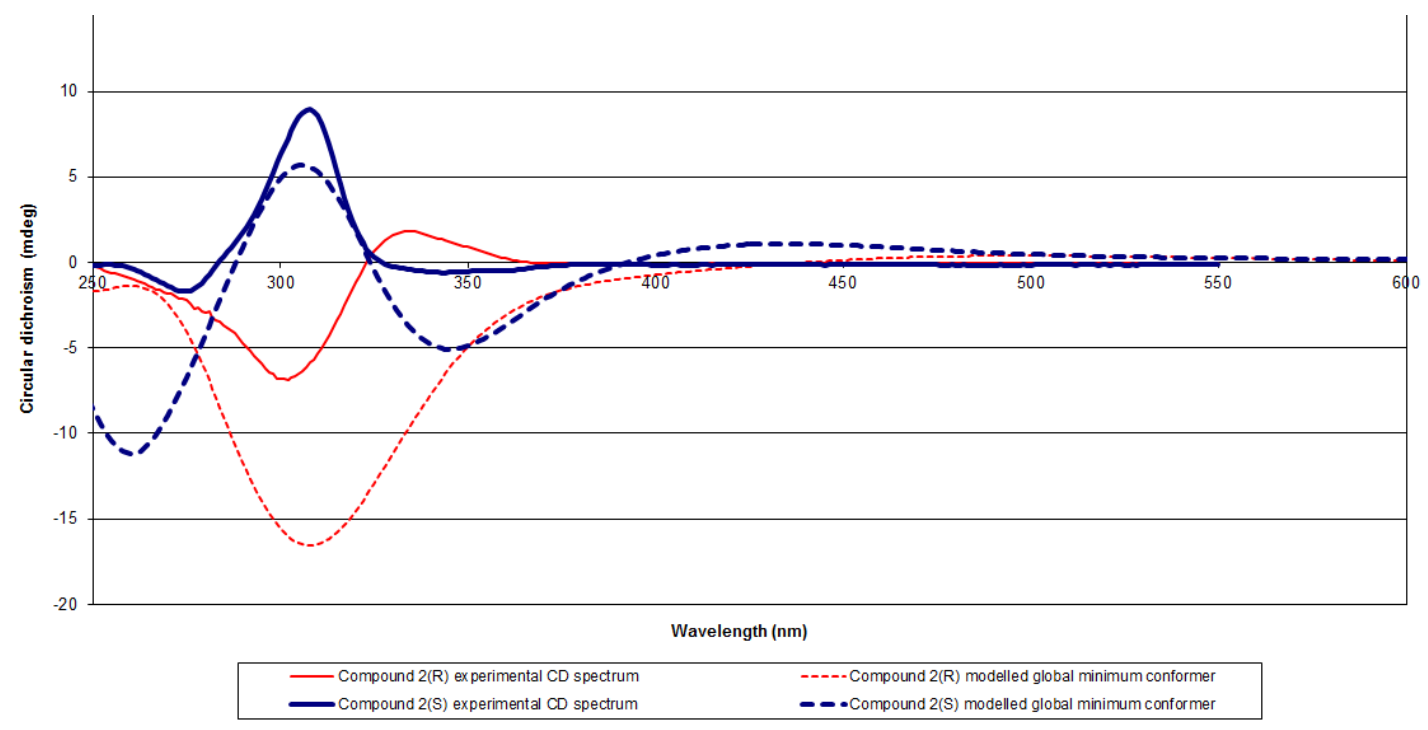

Fig. 2 The experimental and modelled circular dichroism analysis of Compound 2 
Table 2: The percentage cyclooxygenase-2 activity of Compounds 1-3 and 5Ac-13

\begin{tabular}{lcc}
\hline Compound & COX-2 $\%$ activity at $10 \mu \mathrm{M}$ & COX-1 \% activity at $10 \mu \mathrm{M}$ \\
\hline 1 & $101.1 \% \pm 32.6 \%$ & \\
$2(R)$ & $66.7 \% \pm 17.5 \%$ & \\
$2(S)$ & $89.0 \% \pm 29.2 \%$ & \\
3 & $54.4 \% \pm 25.7 \%$ & $57 \% \pm 10.2 \%$ \\
5 acetate & $0 \% \pm 7.8 \%$ & $56 \% \pm 10.7 \%$ \\
6 & $0 \% \pm 21.3 \%$ & $54 \% \pm 15.1 \%$ \\
7 & $0 \% \pm 5.4 \%$ & \\
8 & $73.8 \% \pm 21.4 \%$ & $73.8 \% \pm 8.0 \%$ \\
9 & $62.2 \% \pm 21.4 \%$ & \\
10 & $0 \% \pm 8.3 \%$ & \\
11 & $13.3 \% \pm 13.3 \%$ & \\
12 & $20.9 \% \pm 13.0 \%$ & \\
13 & $71.4 \% \pm 20.0 \%$ & \\
& & \\
Controls*: & & \\
DuP-697 & $47.0 \% \pm 15.5 \%$ & \\
SC-560 & $76.7 \pm 16.0 \%$ &
\end{tabular}

*Footnote

Compounds SC-560 and DuP-607 are positive controls for COX-1 and COX-2 respectively (Cayman Chemical Company, 2011). SC-560 at a concentration of 354 $\mathrm{nM}$ had a significant inhibitory effect on COX-1, but not COX-2, enzyme activity. Similarly, DuP-607 at 304 nM had a significant effect on COX-2 and not COX-1. 


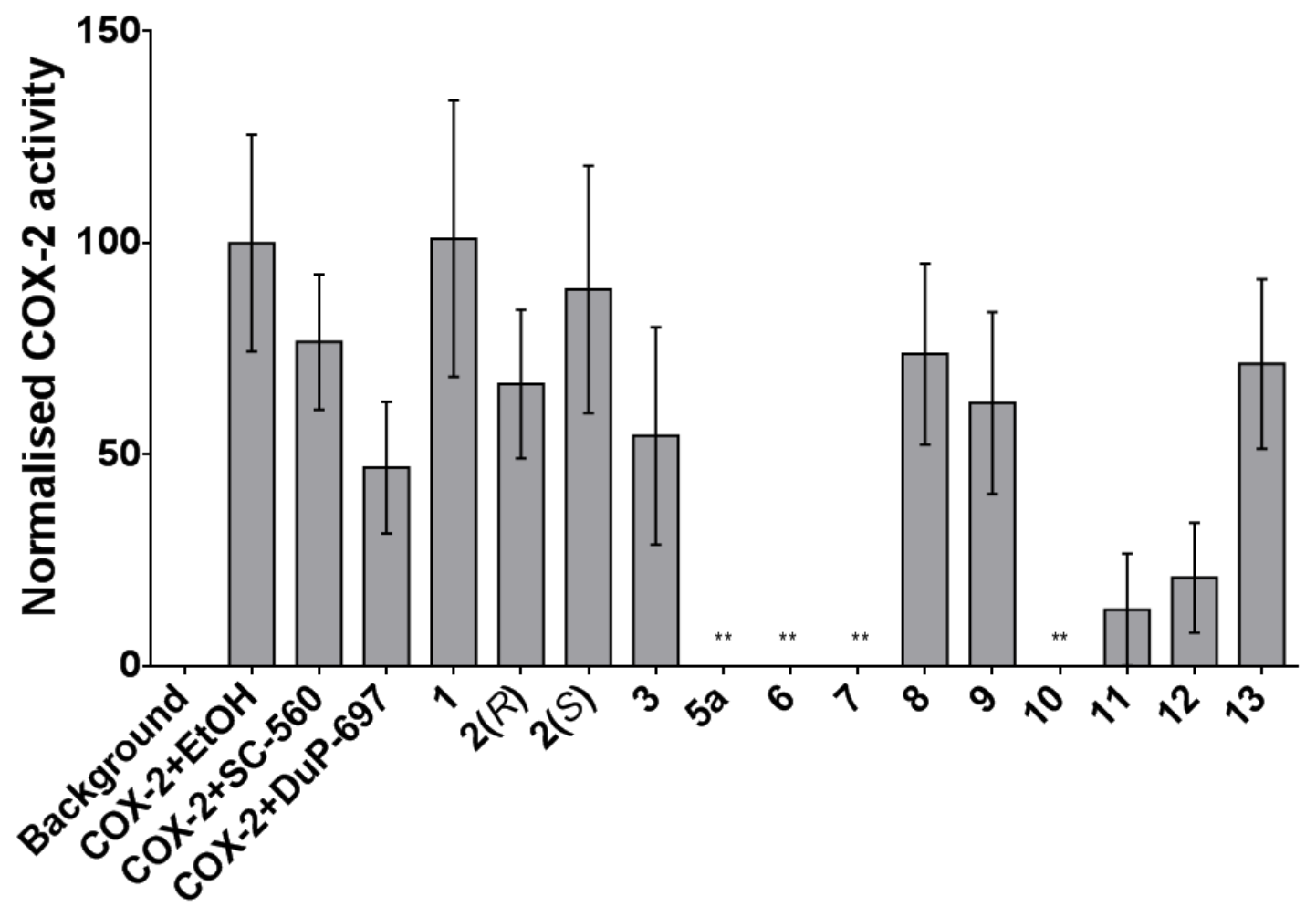

Fig. 3 The percentage cyclooxygenase-2 activity of Compounds 1-3 and 5 acetate-13 
Table 1: ${ }^{1} \mathrm{H}$ NMR (500 MHz) and ${ }^{13} \mathrm{C}$ NMR (125 MHz) data for compounds $1,2(R)$ and $2(S)$ (in $\left.\mathrm{CDCl}_{3}\right)$ and 5 acetate (in MeOD)

\begin{tabular}{|c|c|c|c|c|c|c|c|c|}
\hline \multirow[t]{2}{*}{ No. } & \multicolumn{2}{|r|}{1} & \multicolumn{2}{|r|}{$2(R)$} & \multicolumn{2}{|r|}{$2(S)$} & \multicolumn{2}{|r|}{5 acetate } \\
\hline & ${ }^{13} \mathrm{C}$ NMR & ${ }^{1} \mathrm{H}$ NMR & ${ }^{13} \mathrm{C} \mathrm{NMR}$ & ${ }^{1} \mathrm{H}$ NMR & ${ }^{13} \mathrm{C}$ NMR & ${ }^{1} \mathrm{H}$ NMR & ${ }^{13} \mathrm{C}$ NMR & ${ }^{\mathrm{l}} \mathrm{H}$ NMR \\
\hline $\begin{array}{l}2 \mathrm{~A} \\
2 \mathrm{~B}\end{array}$ & $73.7 \mathrm{CH}_{2}$ & $\begin{array}{l}4.55 * \\
4.54 *\end{array}$ & $97.1 \mathrm{CH}$ & $6.48, \mathrm{~s}$ & $96.7 \mathrm{CH}$ & $6.58, \mathrm{~s}$ & $67.9 \mathrm{CH}_{2}$ & $5.30, \mathrm{~d}, J=1.4 \mathrm{~Hz}$ \\
\hline 3 & $54.5 \mathrm{C}$ & & $56.6 \mathrm{C}$ & & $57.3 \mathrm{C}$ & & $128.9 \mathrm{C}$ & \\
\hline 4 & $196.2 \mathrm{C}$ & & $188.2 \mathrm{C}$ & & $185.9 \mathrm{C}$ & & $180.4 \mathrm{C}$ & \\
\hline $4 \mathrm{a}$ & $102.4 \mathrm{C}$ & & $107.2 \mathrm{C}$ & & $107.2 \mathrm{C}$ & & $165.4 \mathrm{C}$ & \\
\hline 5 & $164.9 \mathrm{C}$ & & $151.9 \mathrm{C}$ & & $152.1 \mathrm{C}$ & & $170.4 \mathrm{C}$ & \\
\hline 6 & $95.4 \mathrm{CH}$ & $6.09, \mathrm{~d}, J=2.3 \mathrm{~Hz}$ & $105.8 \mathrm{CH}$ & $6.33, \mathrm{~d}, J=2.4 \mathrm{~Hz}$ & $105.8 \mathrm{CH}$ & $6.36, \mathrm{~d}, J=2.4 \mathrm{~Hz}$ & $105.9 \mathrm{CH}$ & $6.19, \mathrm{~d}, J=2.3 \mathrm{~Hz}$ \\
\hline 7 & $168.2 \mathrm{C}$ & & $165.9 \mathrm{C}$ & & $166.0 \mathrm{C}$ & & $153.1 \mathrm{C}$ & \\
\hline 8 & $94.4 \mathrm{CH}$ & $6.05, \mathrm{~d}, J=2.3 \mathrm{~Hz}$ & $100.6 \mathrm{CH}$ & $6.43, \mathrm{~d}, J=2.4 \mathrm{~Hz}$ & $100.5 \mathrm{CH}$ & $6.48, \mathrm{~d}, J=2.4 \mathrm{~Hz}$ & $101.4 \mathrm{CH}$ & $6.26, \mathrm{~s}^{* * *}$ \\
\hline $8 \mathrm{a}$ & $163.3 \mathrm{C}$ & & $160.0 \mathrm{C}$ & & $160.0 \mathrm{C}$ & & $164.5 \mathrm{C}$ & \\
\hline $\begin{array}{l}9 \mathrm{~A} \\
9 \mathrm{~B}\end{array}$ & $33.6 \mathrm{CH}_{2}$ & $\begin{aligned} 3.02, \mathrm{~d}, J & =13.1 \mathrm{~Hz} \\
3.62, \mathrm{~d}, J & =13.1 \mathrm{~Hz}\end{aligned}$ & $37.6 \mathrm{CH}_{2}$ & $\begin{array}{l}3.33, \mathrm{~d}, J=13.5 \mathrm{~Hz} \\
3.20, \mathrm{~d}, J=13.5 \mathrm{~Hz}\end{array}$ & $31.1 \mathrm{CH}_{2}$ & $\begin{array}{l}3.84, \mathrm{~d}, J=13.9 \mathrm{~Hz} \\
2.74, \mathrm{~d}, J=13.9 \mathrm{~Hz}\end{array}$ & $137.5 \mathrm{CH}$ & $7.58, \mathrm{~s}$ \\
\hline 1 ' & $118.0 \mathrm{C}$ & & $133.8 \mathrm{C}$ & & $135.5 \mathrm{C}$ & & $147.9 \mathrm{C}$ & \\
\hline 2 ' & $145.2 \mathrm{C}$ & & $105.7 \mathrm{CH}$ & $6.67, \mathrm{~s}$ & $103.9 \mathrm{CH}$ & $6.42, \mathrm{~s}$ & $123.6 \mathrm{CH}$ & $6.80, \mathrm{~d}, J=1.8 \mathrm{~Hz}$ \\
\hline 3 & $137.1 \mathrm{C}$ & & $149.3 \mathrm{C}$ & & $148.9 \mathrm{C}$ & & $145.8 \mathrm{C}$ & \\
\hline 4 & $154.0 \mathrm{C}$ & & $148.0 \mathrm{C}$ & & $147.2 \mathrm{C}$ & & $126.8 \mathrm{C}$ & \\
\hline 5, & $99.4 \mathrm{CH}$ & $6.29 \mathrm{~s}$ & $105.2 \mathrm{CH}$ & $6.61, \mathrm{~s}$ & $106.1 \mathrm{CH}$ & $6.67, \mathrm{~s}$ & $115.7 \mathrm{CH}$ & $6.85, \mathrm{~d}, J=8.2 \mathrm{~Hz}$ \\
\hline 6 ' & $139.2 \mathrm{C}$ & & $131.8 \mathrm{C}$ & & $134.8 \mathrm{C}$ & & $117.4 \mathrm{CH}$ & $6.76, \mathrm{dd}, J=8.2,1.8 \mathrm{~Hz}$ \\
\hline $\begin{array}{l}\text { 7'A } \\
\text { 7'B }\end{array}$ & & & $100.3 \mathrm{CH}_{2}$ & $\begin{array}{l}5.91, \mathrm{~d}, J=1.3 \mathrm{~Hz} \\
5.89, \mathrm{~d}, J=1.3 \mathrm{~Hz}\end{array}$ & $100.3 \mathrm{CH}_{2}$ & $\begin{array}{l}5.86, \mathrm{~d}, J=1.2 \mathrm{~Hz} \\
5.82, \mathrm{~d}, J=1.2 \mathrm{~Hz}\end{array}$ & & \\
\hline $7-\mathrm{OCH}_{3}$ & $56.0 \mathrm{CH}_{3}$ & $3.84 \mathrm{~s}$ & $56.2 \mathrm{CH}_{3}$ & $3.84, \mathrm{~s}$ & $56.2 \mathrm{CH}_{3}$ & $3.86, \mathrm{~s}$ & & \\
\hline $5-\mathrm{COOCH}_{3}$ & & & $21.1 \mathrm{CH}_{3}$ & $2.09, \mathrm{~s}$ & $21.1 \mathrm{CH}_{3}$ & $2.06, \mathrm{~s}$ & $20.3 \mathrm{CH}_{3}$ & $2.33, \mathrm{~s}$ \\
\hline $5-\mathrm{COOCH}_{3}$ & & & $169.5 \mathrm{C}$ & & $169.5 \mathrm{C}$ & & $170.4 \mathrm{C}$ & \\
\hline$\overline{5-\mathrm{OH}}$ & & $12.05 \mathrm{~s}$ & & & & & & \\
\hline $2-\mathrm{COOCH} \underline{\underline{H}}_{3}$ & & & $21.3 \mathrm{CH}_{3}$ & $2.32, \mathrm{~s}$ & $21.3 \mathrm{CH}_{3}$ & $2.33, \mathrm{~s}$ & & \\
\hline $2-\mathrm{COOCH}_{3}$ & & & $169.6 \mathrm{C}$ & & $169.7 \mathrm{C}$ & & & \\
\hline$\overline{2}-\mathrm{OH}$ & & $5.84, \mathrm{~s}$ & & & & & & \\
\hline 3'- $-\mathrm{OCH}_{3}$ & $61.3 \mathrm{CH}_{3}$ & $3.86, \mathrm{~s}$ & & & & & & \\
\hline 4'- $-\mathrm{OCH}_{3}$ & $56.5 \mathrm{CH}_{3}$ & $3.80, \mathrm{~s}$ & & & & & & \\
\hline
\end{tabular}

*non-first order coupling

*** doublet unresolved 